\title{
Conceptual metaphors and emotion expressions in the English for Specific Purposes classroom
}

Metáfora conceptual y vocabulario de emociones en el aula de inglés para fines específicos

ANTONIO-JOSÉ SILVESTRE-LÓPEZ

UNIVERSITAT JAUME I

VICENT BELTRÁN-PALANQUES

UNIVERSITAT JAUME I

RESUMEN: Buena parte de los estudios que abordan la metáfora conceptual en el ámbito docente describen propuestas pedagógicas centradas en la enseñanza de vocabulario (por ejemplo, Boers, 2000, 2013; Littlemore, 2009; Cortés de los Ríos and Sánchez, 2017). Estas propuestas aportan contribuciones significativas al campo de la enseñanza y aprendizaje del inglés. A pesar de interés que suscitan en el campo, no se ha prestado suficiente atención a los efectos de la instrucción de vocabulario basada en metáforas conceptuales (Boers, 2013). Este estudio trata de contribuir a esta línea de investigación explorando los efectos de una propuesta pedagógica centrada en la enseñanza de vocabulario metafórico relativo a dos emociones básicas (alegría y tristeza). El estudio se enmarca en el contexto de la educación superior en España, concretamente en una asignatura de inglés para fines específicos impartida en un grado universitario de psicología. Para evaluar el conocimiento previo de los participantes y su progreso tras la instrucción recibida se adoptó un diseño pre-experimental basado en medidas pre y post-test. Para analizar el rendimiento de los estudiantes se utilizó una prueba de $\mathrm{T}$ y se calculó la magnitud del efecto con la $d$ de Cohen. Los resultados muestran efectos significativos del enfoque pedagógico empleado y una gran magnitud del efecto, indicando de este modo eficacia de la instrucción. Los resultados de este estudio desvelan el potencial de esta área, así como la necesidad de llevar a cabo futuras investigaciones con diseños experimentales.

Palabras clave: metáfora conceptual, vocabulario, expresión de la emoción, educación superior, inglés para fines específicos, aprendizaje de lenguas.

ABSTRACT: The bulk of studies dealing with conceptual metaphors in the language classroom describe conceptual metaphor-based pedagogical proposals to teach vocabulary (e.g., Boers, 2000, 2013; Littlemore, 2009; Cortés de los Ríos and Sánchez, 2017). All these are substantial contributions to the field of English language teaching and learning. Despite the growing interest in the field, the 
effects of conceptual metaphor-based vocabulary instruction on learners still require further attention (Boers, 2013). This paper is an attempt to advance this line of research by exploring the effects of instruction of a pedagogical proposal to teach metaphorical vocabulary belonging to two basic emotions (happiness and sadness). The study is set in a Spanish higher education context, particularly in an English for Specific Purposes subject offered in the Bachelor's Degree in Psychology. A pre-experimental design consisting of pre-test and post-test measures was adopted to gauge participants' previous knowledge and progress after instruction. In order to analyse participants' performance, a paired-sample T-test was used, and effect size was calculated by applying Cohen's $d$. Results show statistically significant effects of the pedagogical approach as well as a large size effect, which reveals the efficacy of the instruction. This exploratory study suggests that this area deserves further investigation and its findings set the ground for future research involving experimental designs.

Key words: conceptual metaphor, vocabulary, emotion expressions, higher education, English for Specific Purposes, language learning.

\section{INTRODUCTION}

Metaphorical language is pervasive in psychological talk. In fact, in order to talk about psychological experiences related to mental states, feelings, or emotions, metaphorical language is the norm (Kövecses, 1990, 2000, 2010; Lakoff, 1993; Lakoff and Johnson, 1999; Silvestre-López and Navarro, 2017). Apart from facilitating communication about inner events by bridging direct (first-person) and shared (thirdperson) experience, metaphors fulfil several important ideational and communicative functions. For example, they are commonly used to facilitate understanding of abstract concepts, to help to reconceptualise complex domains of experience for particular communicative purposes like persuading an audience or grasp their attention, or to awaken emotions (Charteris-Black, 2004; Semino, 2008; Goatly, 2011; Navarro, 2019). While the communicative power of conceptual metaphor has been analysed in general and specialized contexts from the perspective of discourse analysis, its pedagogical potential in language learning still needs further exploration, particularly in the context of English for Specific Purposes. Framed within an innovation in language learning and teaching perspective (Carless, 2013), this study pursues to explore the effects of a metaphor-based approach to deal with emotion-related vocabulary in the context of language for specific purposes in higher education.

\section{THEORETICAL BACKGROUND: CONCEPTUAL METAPHOR THEORY}

Under their most traditional (and generalised) conception, metaphors are regarded as figures of speech that allow us to describe one thing in terms of another and that are often used with some rhetorical purpose. In the early 80's, however, the introduction of Conceptual Metaphor Theory by Lakoff and Johnson (1980) sparked a cognitive turn that revolutionised the study of metaphor in the field of linguistics (cf. Lakoff, 1993; Lakoff and Johnson, 1999; Steen, 2011). According to this theory, metaphors are not just linguistic devices through which one thing can be described in terms of another, but also cognitive mechanisms through which one area of experience - the target domain- can be structured, experienced and understood in terms of another -the source domain. The 
target domain is typically an abstract concept or a complex area of experience (e.g. time, economics, life, freedom, emotions), whereas the source domain is usually more concrete, simpler and/or more familiar to metaphor users (e.g. physical motion, spatial locations, material objects, food, plants). Thus, conceptual metaphors like, say, LIFE IS A JOURNEY facilitate our understanding of LIFE (target domain) in terms of a more physicallygrounded set of experiences related to the domain of JOURNEYS (source domain). This is possible because the conceptual metaphor allows a series of conceptual correspondences (mappings) to be established between a selection of elements in the target domain and their counterparts in the source domain. For example, under the logic of the conceptual metaphor, people in the domain of LIFE are understood as travellers in the domain of JOURNEYS, living a life as walking the way (travelling), stages in life as places we visit, problems in life as obstacles in the journey, objectives or purposes in life as destinations, and so on so forth (Lakoff, 1993; Lakoff and Johnson, 1980).

In Conceptual Metaphor Theory, conceptual metaphors are assumed to be primarily conceptual phenomena, but as mental structures they can be materialised through different modes of expression, like verbal language, gestures, sounds, music, or pictures among others (cf. Forceville and Urios-Aparisi, 2009). When conceptual metaphors are realised verbally, the linguistic expressions they give rise to are called metaphorical expressions. Hence, the conceptual metaphor LIFE IS A JOURNEY allows us to deal with life experiences with expressions that belong to the domain of travelling, for instance: Very few people are bold enough to take the less-travelled road; It's been a long journey for him, but now that he's retired he can enjoy a well-deserved rest; She's managed to reach her so-longed position in spite of the many obstacles she found in the way, and so forth.

Most English language speakers would ordinarily talk about such life experiences using these terms -or very similar ones- and their metaphorical nature would go unnoticed in most occasions because, due to repeated use, these expressions have become conventionalised and are ordinarily used unconsciously by language users (Bowdle and Gentner, 2005). LIFE IS A JOURNEY is a structural metaphor -a conceptual metaphor that structures a large area of experience, often with a wide variety of mappings- that captures two fundamental domains of human experience. It is widely used in English to structure a wide range of conventionalised metaphorical expressions about the domain of LIFE. Nonetheless, - probably due to the conceptual centrality of the domains of human experience it captures- it is also embedded in many other cultures and exploited in other languages besides English, with different degrees of similarity among them (cf. Kövecses, 2005). For example, some English expressions like The new baby has just arrived or Anne is at a crossroads and needs to make up her mind quickly have direct counterparts in other languages like, say, Spanish: Ya ha llegado el bebé tan esperado or Ana está en una encrucijada, necesita tomar una decisión ya. However, variation can also be found across languages that exploit the same conceptual metaphor. Hence, other conventionalised expressions like To be over the hill do not have a direct equivalent in Spanish. Although slightly equivalent expressions can be found in Spanish -e.g. Estar acabado (to have had it, to be sunk), or Ser muy viejo para algo (to be too old for something)-, they are not fully equivalent semantically or simply do not exploit the metaphor. Examples like the ones described above show conceptual metaphors as capturing large domains of experience that are grounded in shared socio-cultural knowledge. However, conceptual metaphors are also systematically used to structure our understanding of 'smaller' domains that are closer to more subjective, direct personal experience such as internal events, mental states, thoughts or emotions (Barnden, 1997). In the case of the latter, when the emotion becomes the target domain of a conceptual metaphor, different components become 
emphasised depending on the source domains with which it is associated (cf. Kövecses, 2000; Kövecses et al., 2016). For example, in emotions like happiness and sadness, a similar set of source domains are frequently recalled in English and Spanish, which results in a cluster of conceptual metaphors that sanction a particular set of expressions in each language. Thus, pairs like HAPPINESS IS UP and SADNESS IS DOWN yield expressions like To be on cloud nine and Estar en el séptimo cielo, or To feel down and Tener la moral baja, among others. The same holds for pairs like HAPPINESS IS LIGHT and SADNESS IS DARKNESS, Or HAPPINESS IS WARMTH and SADNESS IS COLD (Grady, 1997; Kövecses, 2000). Nevertheless, as in the case of large-scale metaphors like LIFE IS A JOURNEY, there are particular target domain-source domain pairings that can only be found in one language and therefore no equivalents can be found in other languages. This is, for example, the case of the conceptual metaphor SADNESS IS BLUE, which sanctions the use of expressions like To feel blue in English, but no equivalent is found in Spanish.

\section{CONCEPTUAL METAPHOR AND LANGUAGE TEACHING}

The variety of conceptual metaphors discussed above can be exploited in a number of ways in general English as a second/foreign language contexts (cf. Piquer-Píriz and Alejo, 2016) as well as in specialised contexts, these including English for Specific Purposes in higher education. For instance, raising learners' awareness about the existence of metaphors (e.g., conventionalised expressions used unconsciously), how conceptual metaphors work in organizing cultural knowledge and language, and/or how conceptual metaphors structure particular sets of expressions in their first language and the second/foreign language may have a positive impact on learners in terms of enhanced engagement, learning pace and vocabulary retention (Boers, 2000, 2013; Boers and Lindstromberg, 2008; Littlemore, 2009; Piquer-Píriz, 2008).

Regarding cultural and linguistic variation, Chen and Lai (2014) survey the effect of cultural universality and specificity in conceptual metaphor comprehension on a group of Taiwanese EFL learners, and report positive and negative performance effects as associated to convergent and divergent first language/foreign language metaphorical patterns respectively. These findings suggest that intercultural and interlinguistic differences are also an important factor to bear in mind when bringing metaphors to the English as a foreign language classroom. In this concern, Chen (2016) and Kalyuga and Kalyuga (2008) address the topic of explicit metaphorical instruction -raising awareness of the concepts and mappings involved in a given set of conceptual metaphors and expressions- and highlight its positive effects in the retention of figurative language at different proficiency levels. Likewise, Doiz and Elizari (2013), who focus on the use of metaphorical expressions associated with anger, contend that raising learners' awareness of the metaphors behind foreign language expressions allows them to use that knowledge consciously to facilitate learning, which benefits learners' acquisition of vocabulary. Other studies tackling metaphorically-grounded idiomatic expressions in second/foreign language pedagogical contexts have also brought the notion of awareness to the spotlight. Thus, Beréndi et al. (2008), Chen and Lai (2013) or Kömür and Çimen (2009), for example, report awareness about the conceptual metaphors behind idiomatic expressions as a key factor in successfully comprehending and remembering idioms in the foreign language, while other studies like Skoufaki (2008) account for awareness about the motivation of foreign language idioms as an efficient facilitator of their comprehension and retention.

The bulk of studies on conceptual metaphor carried out in the field of English for Specific Purposes focus on the usefulness of metaphor in teaching specialised vocabulary. 
Thus, studies such as those conducted by Velasco-Sacristán (2004) or Cortés de los Ríos and Sánchez (2017) present didactic proposals for the teaching of metaphorical vocabulary in the field of Business English, suggesting, in general terms, that these may serve to develop learners' metaphorical competence (cf. Danesi, 1992; 2008; Littlemore and Low, 2006a; 2006b). Velasco-Sacristián (2009) emphasises the role of translation for the teaching of metaphorical vocabulary in the context of Business English. Another example is found in the context of Legal English where Campos-Pardillos (2016) proposes a pedagogical approach to teach metaphorical vocabulary based on raising learners' awareness. Overall, the main concern of these studies is presenting pedagogical proposals that can be taken as steps forward towards the inclusion of metaphor-based activities in the second/foreign language and English for Specific Purposes curricula. As such, all of them are substantial contributions to the teaching of specialised lexicon in specific academic and professional contexts. Nevertheless, Boers (2013) already emphasised the need for more experimental studies addressing the effects of instruction of metaphor-based activities. Despite the growing interest in how metaphors can foster second/foreign language learning, and the proliferation of contributions providing pedagogical insights into this realm, the effects of instruction are seldom analysed.

\section{AIM OF THE STUDY}

The study conducted here attempts to contribute to this call for empirical studies in the metaphor research arena. To that end, we present a study that adopts a preexperimental design to survey the effects of instruction of a pedagogical proposal to teach vocabulary based on conceptual metaphors. More specifically, the proposal deals with metaphorical expressions derived from a selection of conceptual metaphors belonging to the domain of emotions (i.e., happiness and sadness) in a higher education English for Specific Purposes context.

\section{METHODOLOGY}

\subsection{PARTICIPANTS}

A group of 64 Spanish students of English for Specific Purposes majoring the Degree of Psychology at a Spanish university volunteered to take part in the study. All of them were bilingual (Catalan-Spanish/Spanish-Catalan). Then, a proficiency level test (Quick Placement Test, 2001) was administered in order to classify potential participants into different proficiency levels. Test results placed the participants into the following proficiency levels: 9 in A2, 38 in B1, 15 in B2 and 2 in C1 level according to the Common European Framework of Reference for Languages (CEFR, 2001). Based on group size, only students belonging to the B1 group were considered in the study. The rest were discarded because we attempted to implement the study with a homogenous group in terms of proficiency level. During the implementation, some participants were discarded due to absence or failure to complete one or various parts of the activities or tests requested. This yielded a final group of 34 participants $(28$ female and 6 male, ages ranging from 19 to 21 ).

\subsection{MEASUREMENT INSTRUMENT}

Following a one-group pre-experimental design, this study involves the use of a pre-test and post-test instrument to measure the effects of instruction (Porte, 2010; 
Privitera, 2017). The instrument was devised to gauge participants' knowledge as regards expressions related to the domains of happiness and sadness. It comprises 10 fill-in-thegap questions (Cf. Appendix A), thereby allowing for comparability of scores before and after the pedagogical treatment. The instrument served to gather quantitative data based on participants' scoring. It was revised by two language teachers, who were not involved in the study presented here, and then piloted with a different group of students of English for Psychology $(\mathrm{N}=21)$ during the previous academic year (2016/2017). Drawing on the feedback and the results of the pilot study, the final version of the test was created.

\subsection{DATA COLLECTION PROCEDURE AND PEDAGOGICAL TREATMENT}

Data were collected during the second term (mid-April) of the 2017/2018 academic year at a Spanish university. Since the study was implemented as part of the content of the English for Specific Purposes subject, the group was informed of the time frame for the study, and participants' permission was requested before implementing it. The students that were discarded due to proficiency issues $(\mathrm{N}=26)$ in previous stages are not considered in the study presented. Nevertheless, the whole group completed the activities since these were presented to them as part of the ordinary tasks of the unit. As illustrated in Table 1, the implementation of the study involved four different sessions.

Table 1. Schematic representation of the implementation of the study

\begin{tabular}{|c|c|c|}
\hline Session & Procedure & $\begin{array}{c}\text { Time per } \\
\text { session }\end{array}$ \\
\hline 1 & Proficiency level test & 1 hour \\
\hline 2 & $\begin{array}{c}\text { Permission } \\
\text { Pre-test } \\
\text { Warm-up phase }\end{array}$ & 2 hours \\
\hline 3 & $\begin{array}{c}\text { Practice phase } \\
\text { Post-test }\end{array}$ & 1 hour \\
\hline 4 & $\begin{array}{c}\text { Metaphorical awareness and discussion } \\
\text { Pon }\end{array}$ & 2 hours \\
\hline
\end{tabular}

As observed in Table 1, the four sessions were devoted to selecting the participants of the study, collecting data, and implementing the pedagogical treatment. More specifically, the time frame for the study shown above was followed (i) to administer the proficiency level test (completed online); (ii) to ask for permission to collect data; (iii) to administer the pre-test (completed online); (iv) to implement the pedagogical treatment in three phases (warm-up, practice, metaphorical awareness and discussion); and (v) to administer the post-test (completed online).

The pedagogical proposal used to teach metaphorical vocabulary was adapted from previous research (Sanz, 2015) and tailored for an English for Specific Purposes course in the Bachelor's Degree mentioned above. The pedagogical treatment was based on a selection of conceptual metaphors that structure part of the vocabulary of two basic emotions in the English language: happiness and sadness. More specifically, happiness and sadness were taken as the target domain of a series of conceptual metaphors, which, in combination with a closed set of complementary source domains, provide an orderly 
and logical structure to a series of expressions derived from each of them. Concretely, the conceptual metaphors involved in the study are: HAPPINESS IS UP, HAPPINESS IS WARMTH, HAPPINESS IS LIGHT, and SADNESS IS DOWN, SADNESS IS COLD, SADNESS IS DARKNESS. The choice of happiness and sadness as target emotions for our study was motivated because they are two basic emotions; they are structurally simpler and more easily appraised by all human beings (Ekman, 1995). On the other hand, the conceptual metaphors mentioned above are also grounded in basic physical and perceptual experience, and are themselves basic (primary) associations that permeate culture and language (cf. Grady, 1997). Such conceptual metaphors were thus assumed to be easily recognised (as part of their everyday experience) and understood by learners.

The pedagogical treatment involved three sets of activities consisting of three different phases, namely: (1) warm-up, (2) practice, (3) conceptual metaphor awareness and discussion (cf. Appendix B). During the first phase, the participants were provided with a set of expressions in English that are related to happiness and sadness. The participants were asked to talk in pairs and discuss which emotions they thought each expression would typically evoke.

Through peer and group discussion, and with the guidance of the teacher, the participants were encouraged to think of similar expressions in other languages. They were thus guided to discover that some linguistic realisations of emotions can be conventionalised differently in different languages -in this particular case, English and Catalan and/or Spanish. This phase was devised to encourage the participants to start exploring first-hand vocabulary related to happiness and sadness in an inductive (bottomup) fashion, providing them with the opportunity to build and share on previous individual and group knowledge. Likewise, this allowed them to develop their own intuitions about how each expression might be categorised as related to a particular emotion, and to establish comparisons between English expressions and those in other languages.

In the second phase, the participants were asked to complete an activity that involves arranging, in two columns, a larger set of expressions according to their perceived similarity; in order to do so, the participants were prompted to follow their intuition to generate a coherent classification pattern. The purpose was to engage the participants in an activity that allowed them to identify inductively the source domains and target domains without receiving any kind of instruction about what conceptual metaphors, target domains or source domains are. The whole group were encouraged to discuss their classification and comment on all matching and divergent answers. During the discussion -at this point guided by the teacher- further examples of the expressions in contexts were provided, and their meaning was addressed explicitly in class. Students were also guided by the teacher to discriminate among potential equivalent expressions based on fine meaning distinctions or nuances, as for example, To be in a dark mood as opposed to To get someone down.

The participants were then asked to provide a 'heading' for each column encompassing the expressions they had just classified, which yielded the labels 'happiness' and 'sadness'. This helped the teacher to introduce the idea of affectively positive and negative emotions (a topic connected to the participants' area of expertise), and to establish a connection between the labels they had just provided, together with the source domains of the conceptual metaphors introduced in the following activity.

The third phase is composed of two activities. In activity 3, the participants were introduced to the notion of 'domain' of experience, and were requested to connect happiness and sadness with a set of domains provided therein. Although it was a newlyintroduced set, it was not fully unknown to them, for they had intuitively inferred these patterns (i.e., target domain-source domains connections) throughout the procedures 
followed in previous activities. Finally, in activity 3, the teacher introduced explicitly for the first time- the notion of conceptual metaphors (as mental structures) and metaphorical expressions (as linguistic structures derived from ready-made metaphorical associations) in the classroom. In so doing, the teacher raised the participants' awareness of conceptual metaphors and metaphorical expressions and the fact that most of the expressions commented so far (in different languages) can be arranged in an orderly way. Keeping explicit instruction on conceptual metaphors to the last phase gave the participants the chance to experiment the pedagogical implementation as an experiential process of self-discovery.

\subsection{DATA ANALYSIS PROCEDURE}

Data were analysed according to participants' scoring in the pre-test and post-test. A correct answer in the test was assigned as 1 point, resulting in a maximum of 10 points in each test. Answers containing spelling, use of English and/or grammatical mistakes were considered as valid responses ( 1 point) provided that the correct metaphorical expression was chosen. When two potential expressions are adequate for the same slot, the students are required to choose the best choice according to the situational context provided in each item. Moreover, wrong vocabulary choices were not penalised but did not score any point. The following example illustrates the scoring system applied in both tests.

\section{Example 1}

Item:

Breaking up with his girlfriend then he realized she wasn't the right girl for him. for several days, but

Possible answer:

Breaking up with his girlfriend got him down for several days, but then he realized she wasn't the right girl for him.

Score: 1

Breaking up with his girlfriend get him down for several days, but then he realized she wasn't the right girl for him.

Score: 1

Breaking up with his girlfriend was in a dark mood for several days, but then he realized she wasn't the right girl for him.

Score: 0

The scoring of each participant was measured following the system presented above. Additionally, a paired sample T-test was applied in order to run statistical analysis of data using Statistical Package for the Social Sciences (SPSS, 25). An alpha level of $\mathrm{p}<0.05^{*}$ was established as the significant level.

\section{RESULTS}

The purpose of this study is to survey the effects of a pedagogical treatment that was implemented as part of the regular sessions of a group of students of an English for Specific Purposes subject at a Spanish university. This section presents results by showing the general performance of the group of participants as associated with the treatment. In terms of specifics, we here report the statistical analysis of the pre-test and 
post-test scores and the effect size. Table 2 shows descriptive statistics of the results obtained in the pre-test and post-test.

Table 2. Descriptive statistics of the pre-test and post-test scores

\begin{tabular}{|c|c|c|c|c|c|}
\cline { 2 - 6 } \multicolumn{1}{c|}{} & $\boldsymbol{N}$ & Min. & Max. & Mean & SD \\
\hline Pre-test & 34 & .00 & 8.00 & 2.8529 & 2.07631 \\
\hline Post-test & 34 & .00 & 10.00 & 5.8529 & 3.00638 \\
\hline
\end{tabular}

The minimum score obtained was 0 for each test and the maximum was 8 in the pre-test and 10 in the post-test. The mean obtained in the post-test (5.8529) was greater than the mean in the pre-test (2.8529), which suggests that there is an overall increase in terms of attainment. Concretely, the mean difference between the pre-test and post-test resulted in a mean score of 3 points. In general, results revealed a general tendency to obtain better scores in the post-test than in the pre-test, that is, after the pedagogical treatment.

A paired sample T-test was then applied. Table 3 shows the statistical analysis run to survey the effects of the pedagogical treatment.

Table 3. Paired sample T-test of the pre-test and post-test results

\begin{tabular}{|c|c|c|c|c|c|}
\cline { 2 - 5 } \multicolumn{1}{c|}{} & Mean & SD. & t-value & $d f$ & Sig \\
\hline $\begin{array}{c}\text { Pre-test and } \\
\text { post-test }\end{array}$ & -3.00000 & 2.25630 & -7.753 & 33 & $.000^{* *}$ \\
$\begin{array}{c}\mathrm{p}<.001^{* *} \\
\text { p }\end{array}$ & & & \\
\hline
\end{tabular}

The paired sample T-test revealed that there was a change in the scores obtained in the pre-test and post-test which proved to be statistically significant (t-value(34)=$\left.7.753, \mathrm{p}<.000^{* *}\right)$. This suggests that, for this particular group of participants, the pedagogical treatment was effective, as there was a statistically significant increase after the implementation. In addition to this, effect size was calculated applying Cohen's $d$ in order to measure the absolute magnitude of the effect of the pedagogical treatment. The outcome of this calculation yielded $\mathrm{d}=1.1611963(\mathrm{~d}>.8)$ and a large positive effect size correlation was found, $\mathrm{r}=0.5021051$. This calculation hints at a large effect, which indicates the efficacy of the treatment and an acceptable degree of generalisation.

The data presented so far describes the general tendency of the group as a whole. In the following lines, we address individualised participants' scores and specific cases. Data derived from the pre-test and post-test allows individual participants performance to be compared after treatment (Porte, 2010). As shown in Figure 1, a focus on individual cases shows that 31 participants out of 34 did better in the post-test than in the pre-test. 
Figure 1. Pre-test and post-test scores

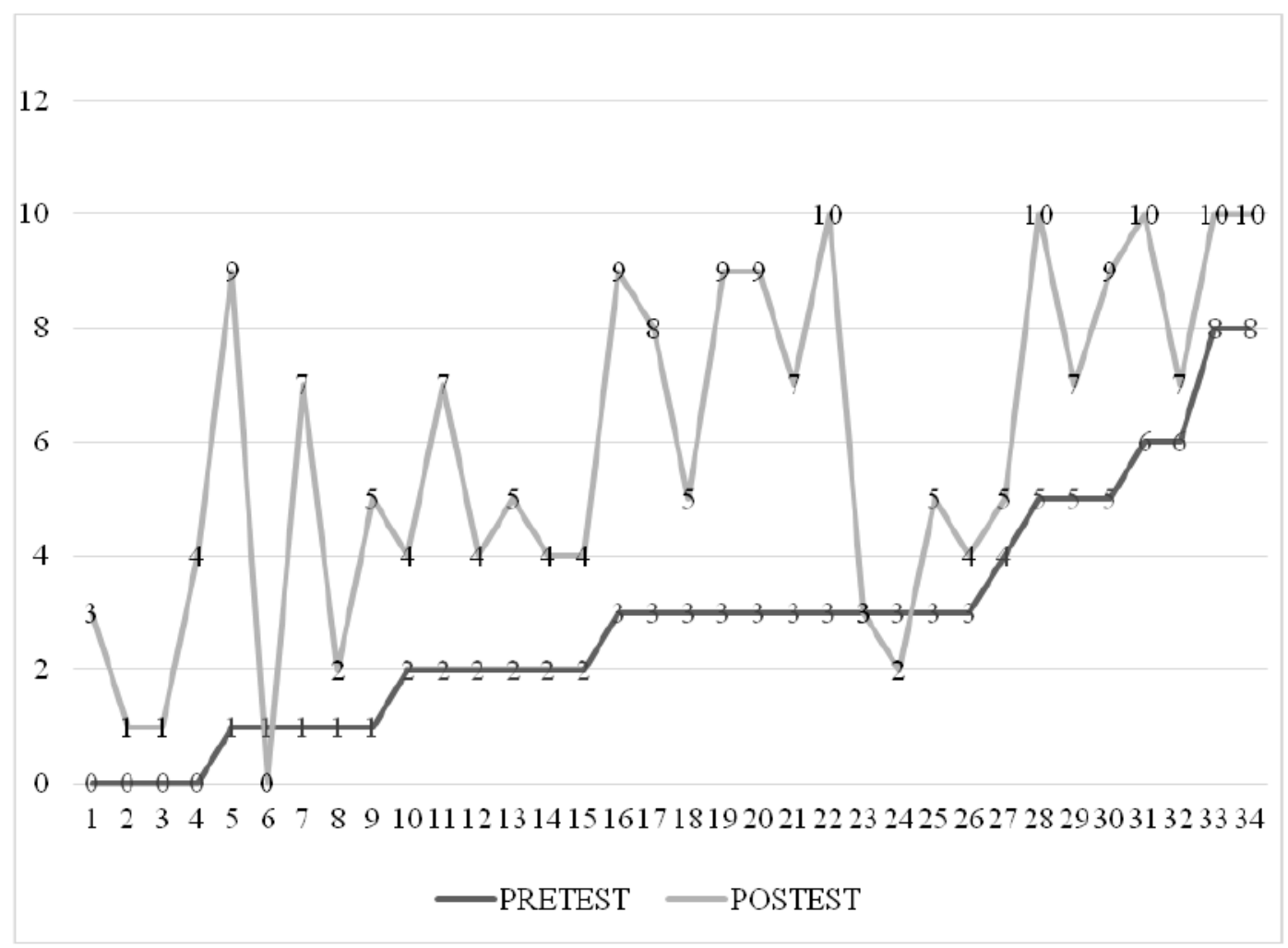

As illustrated above, a large increase can be observed in 9 cases, with a difference of at least 5 points. Among these cases, some participants scored relatively low in the pretest ( 5 or below), but they achieved greater results in the post-test; Specifically, this is the case of participant 5 (1/9), 7 (1/7), 11 (2/7), 16 (3/9), 17 (3/8), 19 (3/9), 20 (3/9), 22 $(3 / 10)$, and $28(5 / 10)$. It can also be observed that two of the participants had a great score in the pre-test (participant 33 and 34), but for obvious reasons -the starting point was $8 / 10$ - their increase was not so relevant ( 2 points each). This particular result may be related to minor individual variation within the same proficiency level. Moreover, it must be mentioned that the proficiency level test measured general knowledge of English in terms of grammatical competence, but it did not measure specific vocabulary of the domain of emotions.

Other participants did not show major differences after the pedagogical treatment. This is the case of those participants whose scoring increased between 1 or 2 points from the pre-test to the post-test. More specifically, this is the case of participant $2(0 / 1), 3$ (0/1), 8 (1/2), 10 (2/4), 12 (2/4), 14 (2/4), 15 (2/4), 18 (3/5), 25(3/5), $26(3 / 4), 27$ (4/5), $29(5 / 7)$, and $32(6 / 7)$. The vast majority of these participants obtained low scores (up to 4) except for participant 29 and 32, who completed correctly at least $50 \%$ of the responses in the pre-test. Slightly greater difference was found in some other participants, whose scoring was found to increase between 3 and 4 points from the pre-test to the post-test, namely participant $1(0 / 3), 4(0 / 4), 9(1 / 5), 13(2 / 5), 21(3 / 7), 30(5 / 9)$, and $31(6 / 10)$. However, the scoring of some participants did not show an increase. Particularly, participants 6 and 24 scored lower in the post-test, and participant 23 remained the same.

\footnotetext{
${ }^{1}$ This information is to be understood as follows: (pre-test score/post-test score).
} 
This may be due to extraneous variables such as different learning paces, learning styles or students' interests and attitudes towards English language learning.

The present analysis of individual performance shows that while participants' tendency was to obtain greater results after the treatment, their attainment was not necessarily relevant in all cases in terms of scoring. All in all, it seems that the vast majority of participants $(\mathrm{N}=31)$ scored better in the post-test than in the pre-test, thereby showing that the pedagogical treatment was generally beneficial for this particular group of participants.

\section{DISCUSSION AND FINAL REMARKS}

Carless (2013: 1) approaches innovation "as an attempt to bring about educational improvement by doing something which is perceived by implementers as new or different". This study embraces Carless' (2013) conception of innovation and attempts to apply it to the context of language teaching and learning. More particularly, the aim of this study was to survey the effect of instruction of a pedagogical proposal based on conceptual metaphors of the domain of emotions to teach metaphorical vocabulary in the English for Specific Purposes context.

In the study, a pre-test and a post-test were administered before and after the pedagogical treatment, which was structured through an inductive approach of selfdiscovery culminating in a final phase of conceptual metaphor awareness raising. Overall, results show that in terms of scoring, the participants of the study increased their knowledge as regards the specific metaphorical vocabulary tackled during the pedagogical treatment. In addition to this, the statistical analysis run in the study revealed significant differences between the pre-test and post-test. Nonetheless, the study would fall short of providing sound evidence about the impact of the pedagogical treatment without analysing effect size. The absolute magnitude of the treatment was measured by applying Cohen's $d$, which resulted in a large effect. Thus, the overall results suggest that the pedagogical treatment undertaken here may also be effective in other groups. Conducting a pre-experimental study has allowed us to identify an area that is worth further exploring. This study can thus be conceived as a preliminary but necessary step to further expand this line of research by following more complex experimental designs involving a larger number of participants. A key aspect to consider in future experimental designs would be including different groups, for example a control group and/or a comparison group (Porte, 2010; Thyer, 2012). In so doing, further comparisons can be established among participants receiving no treatment or a different kind of treatment (e.g., inductive versus deductive procedures), which would in turn shed some light on any potential effects due to instrument reactivity or improvement due to test repetition.

In this study, qualitative observation instruments to gather data about participants' personal experience and performance were not employed. Notwithstanding this, the potential benefits of adding in qualitative information became apparent through participants' explicit comments on their learning experience. That is to say, explicit instruction on conceptual metaphors was performed only during the last phase, which allowed participants to discover by themselves the conceptual metaphor domains that underlie the expression they had been dealing with during the previous phases in an inductive way. Most participants perceived this way of approaching conceptual metaphor in the classroom as engaging and satisfactory (personal communication to the teacher). In particular, awareness of conceptual metaphors and how they worked called the attention of most of them, which could be due to their personal interests (as future psychologists) in how the mind works. 
Combining quantitative and qualitative research instruments would be desirable (Creswell, 2003) in future studies to provide additional insights into participants' performance and perception regarding the adequacy of teaching materials, the appropriateness of the pedagogical process and their engagement in the pedagogical experience. For example, in this particular study, apart from administering a pre-test and post-test (quantitative), it would have been ideal to conduct semi-structured interviews with participants and/or a focus group discussion (qualitative), as well as a delayed posttest to examine participants' retention (quantitative).

Further research should also include a wider range of variables. Potential variables for this line of research may include prior knowledge, proficiency, bilingualism and/or multilingualism, as well as out-of-school factors. Future research addressing the variable of proficiency should focus on how the approach is received across different levels. By the same token, studies tackling the variable of bilingualism and/or multilingualism may focus on aspects such as the influence of participants' first and second language, for instance, by focusing on language transfer in order to examine the degree of coincidence and/or divergence of the linguistic realisations of conceptual metaphors in each language. Similarly, out-of-school factors (e.g., exposure to media or language use out of academic contexts) that might affect participants' knowledge and mastery of vocabulary should also be taken into account. Studies like the one presented here can contribute to a better understanding of the processes of language teaching and learning, and to see how important it is to continue updating teaching methodologies and approaches, and language materials in order to assist language learners. Our contribution is an attempt to explore whether a new pedagogical treatment can benefit learners and, as shown, the innovative approach succeeded in this particular case, but more research is needed to ascertain under which conditions and in which particular contexts such an approach proves optimally successful.

\section{ACKNOWLEDGEMENTS}

We would like to thank the two anonymous reviewers for the useful comments on an earlier version of this paper. We would also like to thank the institutional support received by Universitat Jaume I and the Interuniversity Institute for Applied Modern Languages. The research presented in this paper is farmed within the projects UJI-B201859 (Universitat Jaume I) and GV/2019/101 (Conselleria d'Innovació, Universitats, Ciència i Societat Digital, Generalitat Valenciana).

\section{REFERENCES}

Barnden, John A. 1997. "Consciousness and common-sense metaphors of mind". In Two sciences of mind: Readings in cognitive science and consciousness, eds. Sean O’Nuallain, Paul Mc Kevitt and Eoghan Mac Aogain. Amsterdam: John Benjamins, pp. 311-340.

Beréndi, Márta, Sandra Csábi. and Zoltán Kövecses. 2008. In "Using conceptual metaphors and metonymies in vocabulary teaching", eds. Frank Boers and Seth Lindstromberg Cognitive linguistic approaches to teaching vocabulary and phraseology. Berlin: Mouton de Gruyter, pp. 65-99.

Boers, Frank and Seth Lindstromberg, eds. 2008. Cognitive linguistic approaches to teaching vocabulary and phraseology. Berlin: Mouton de Gruyter.

Boers, Frank. 2000. "Metaphor awareness and vocabulary retention". Applied Linguistics, 21(4): 553-571. 
Boers, Frank. 2013. "Cognitive linguistic approaches to teaching vocabulary: Assessment and integration". Language Teaching, 46(2): 208-224.

Bowdle, Brian F. and Drede Gentner. 2005. "The Career of Metaphor". Psychological Review, 112, 1: 193-216.

Campos-Pardillos, Miguel A. 2016. "Increasing metaphor awareness in legal English teaching". ESP Today, 4(2): 165-183.

Carless, David. 2013. "Innovation in language teaching and learning". In The encyclopedia of applied linguistics, ed. Carol A. Chapelle. Oxford: Blackwell Publishing Ltd., pp. 1-4.

Council of Europe. 2001. Common European Framework of Reference for Languages: Learning, Teaching, Assessment. Strasbourg: Cambridge University press. https://rm.coe.int/1680459f97

Charteris-Black, Jonathan. 2004. Corpus approaches to critical metaphor analysis. New York: Palgrave Macmillan.

Chen, Yi-Chen. 2016. "Teaching figurative language to EFL learners: an evaluation of metaphoric mapping instruction". The Language Learning Journal, 47(1): 49-63

Chen, Yi-Chen and Huei-ling Lai. 2013. "Teaching English idioms as metaphors through cognitive-oriented methods: A case in an EFL writing class". English Language Teaching. 6(6): 13-20.

Chen, Yi-Chen and Huei-ling Lai. 2014. "The influence of cultural universality and specificity on EFL learners' comprehension of metaphor and metonymy". International Journal of Applied Linguistics, 24(3): 312-336.

Cortés de los Ríos, María E. and María M. Sánchez. 2017. "Developing Business English students' metaphorical competence in foreign language learning higher education contexts". ES Review: Spanish Journal of English Studies, 38: 113-138.

Creswell John. W. 2003. Research design: Qualitative, quantitative and mixed methods approaches. Thousand Oaks: Sage Publications.

Danesi, Marcel. 1992. "Metaphorical competence in second language acquisition and second language teaching: The neglected dimension". In Georgetown University round table on language and linguistics, ed. James E. Alans. Washington D.C.: Georgetown University Press, pp. 489-515.

Danesi, Marcel. 2008. "Conceptual errors in second-language learning". In Cognitive approaches to pedagogical grammar: A volume in honour of René Dirven, Sabine De Knop and Teun De Rycker. Berlin: Mouton de Gruyter, pp. 231-256.

Doiz, Aintzane and Carmen Elizari. 2013. "Metaphoric competence and the acquisition of figurative vocabulary in foreign language learning". Estudios de Lingüística Inglesa Aplicada, 13: 47-82.

Ekman, Paul. 1995. "Strong evidence for universals in facial expressions: A reply to Ruissell's mistaken critique”. Pyschological Bulletin, 15: 268-287.

Forceville, Charles and Eduardo Urios-Aparisi, eds. 2009. Multimodal metaphor. Berlin: Mouton de Gruyter.

Goatly, Andrew. 2011. The language of metaphors. $2^{\text {nd }}$ edition. New York: Routledge.

Grady, Joseph E. 1997. Theories are buildings revisited. Cognitive Linguistics, 8.3: 267290.

Kömür, Şevki and Şeyda Selen Çimen. 2009. "Using conceptual metaphors in teaching idioms in a foreign language context". Sosyal Bilimler Enstitütu Dergisi, 23: 205222.

Kövecses, Zoltán. 1990. Emotion concepts. Berlin/New York: Springer.

—. 2000. Metaphor and emotion. Cambridge: Cambridge University Press. 
-. 2005. Metaphor in culture. Universality and variation. Cambridge: Cambridge University Press.

-. 2010. Metaphor: A practical introduction. $2^{\text {nd }}$ edition. Oxford: Oxford University Press.

Kövecses, Zoltán, Veronika Szelid, Eszter Nucz, Olga Blanco-Carrión, Elif Arica Akkök and Réka Szabó. 2016. "Anger metaphors across languages: A cognitive linguistic perspective". In Bilingual figurative language processing, Roberto R. Heredia and Anna B. Cieślicka. Cambridge: Cambridge University Press, pp. 341-367.

Lakoff, George and Mark Johnson. 1980. Metaphors we live by. Chicago: Chicago University Press.

Lakoff, George and Mark Johnson. 1999. Philosophy in the flesh. The embodied mind and its challenge to western thought. New York: Basic Books.

Lakoff, George. 1993. "The contemporary theory of metaphor". In Metaphor and thought, ed. Andrew Ortony. Cambridge: Cambridge University Press, pp. 202251

Lakoff, George. 1996. Moral politics: What conservatives know that liberals don't. Chicago: University of Chicago Press

Littlemore, Jeannette and Graham Low. 2006a. "Metaphoric competence, second language learning, and communicative language ability". Applied Linguistics, (27)2: 268-294.

-. 2006b. Figurative thinking and foreign language learning. Basingstoke: Palgrave Macmillan.

Littlemore, Jeannette. 2009. Applying cognitive linguistics to second language learning and teaching. Basingstoke: Palgrave Macmillan.

Marika Kalyuga and Kalyuga Slava. 2008. "Metaphor awareness in teaching vocabulary". The Language Learning Journal, 36: 249-257.

Navarro, Ignasi, ed. 2019. Current approaches to metaphor analysis in discourse. Berlin: Mouton de Gruyter.

Piquer-Píriz, Ana M. and Rafael Alejo. 2016. “Applying cognitive linguistics: Identifying some current research foci (figurative language in use, constructions and typology)". Review of Cognitive Linguistics, 14(1): 1-20.

Piquer-Píriz, Ana M. 2008. "Reasoning figuratively in early EFL: Some implications for the development of vocabulary". In Cognitive linguistic approaches to teaching vocabulary and phraseology, eds. Frank Boers and Seth Lindstromberg. Berlin: Mouton de Gruyter, pp. 219-240.

Porte, Graeme K. 2010. Appraising research in second language learning. A practical approach to critical analysis of quantitative research. Amsterdam: John Benjamins.

Privitera, Gregory J. 2017. Research methods for the behavioral sciences. $2^{\text {nd }}$ edition. London: SAGE Publications, Inc.

Quick Placement Test (2001). Paper and pen test. Oxford: Oxford University Press.

Sanz, Maria. 2015. Teaching lexicon through metaphors. Master's thesis, Universitat Jaume I, Castelló, Spain. http://hdl.handle.net/10234/144586

Semino, Elena. 2008. Metaphor in discourse. Cambridge: Cambridge University Press.

Silvestre-López Antonio-José and Navarro i Ferrando, Ignasi. 2017. "Metaphors in the conceptualization of meditative practices". Metaphor and the Social World, 7(1): 26-46.

Skoufaki, Sophia. 2008. "Conceptual metaphoric meaning clues in two idiom presentation methods2. In Cognitive linguistic approaches to teaching vocabulary 
and phraseology, eds. Frank Boers and Seth Lindstromberg. Berlin: Mouton de Gruyter, pp. 101-132.

Steen, Gerard J. 2011. "The contemporary theory of metaphor-now new and improved!". Review of Cognitive Linguistics, 9(1): 24-64.

Thyer, Bruce A. 2012. Quasi-experimental research designs. Oxford: Oxford University Press.

Velasco-Sacristán, Marisol. 2004. "Metaphor and ESP: Metaphor as a useful device for teaching L2 business English learners". Ibérica, 10: 115-131.

Velasco-Sacristán, Marisol. 2009. "A translation approach to metaphor teaching in the LSP classroom: Sample exercises from a business English syllabus”. Ibérica, 17: 83-98. 


\section{APPENDIX A}

Complete the sentences below with the expression from the box that best fits its context. Change the form of the expressions when necessary (for example, to adapt an infinitive to the correct verb tense required in the sentence, to provide for the right person-verb agreement, etc.). There are two expressions in the box that you do not need to use.

To cheer up, Low, Radiant, Cold prospect, To be in a dark mood, To get (someone) down, To brighten up, To explode, To get into a depression, To lift, To sink, To walk on air

1. You need to value small things that happen to you every day. It is these little things that your life.

2. ! Things are not as bad as you think.

3. You'll have a really if you leave college now! You need to finish your studies

4. These news will really her spirits. Her future looks brighter now.

5. Her cat passed away last week, so she is a bit now.

6. Simon was with joy after buying the car he had always dreamt of.

7. When Sarah knew she passed her exam, she

8. Before quitting his job he every single day at his workplace. Being surrounded by negative people wasn't good for him.

9. Breaking up with his girlfriend for several days, but then he realized she wasn't the right girl for him.

10. I am afraid she has . She needs to visit a psychologist.

\section{APPENDIX B}

Phase 1: Warm-up

1. Read the following expressions. What emotions do you think they are related to? Discuss your ideas with a partner and be prepared to share them with the rest of the class.

\section{To cheer up To feel a warm joy To feel down To sink}

To brighten up To walk on air To be low

To be in a black mood 
Phase 2: Practice

2. The expressions in the box below are related to different emotions. Place each expression in the left or right column following a coherent pattern for you. You don't need to give a name to the emotions they are related to by now, so leave the heading of each column blank.

To lift someone's spirits

To look up

To shine

To feel a warm joy

To feel a deep sadness

To light up

To brighten up

To get somebody down
To look bright

To feel cold and lonely

To burn with joy

To look radiant with joy

To let someone down

To be in a black mood

To feel blue

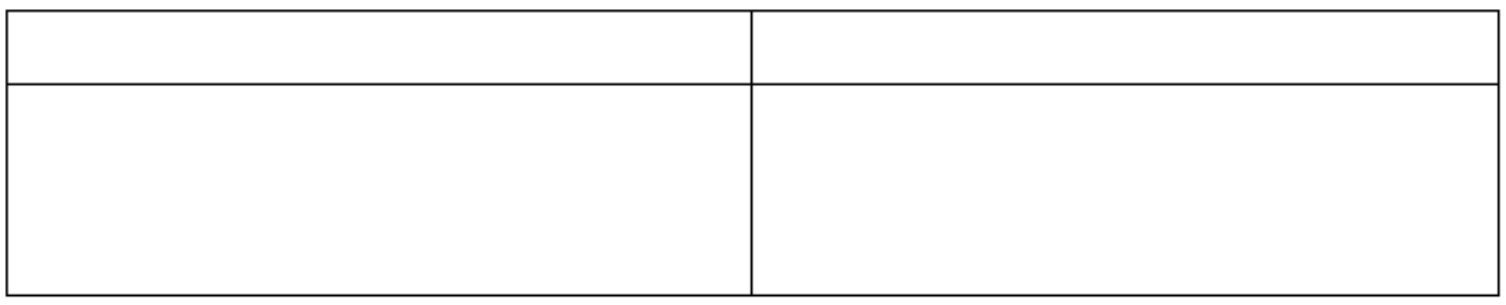

Phase 3: conceptual metaphor awareness and discussion

3. In the box below there are different areas or "domains" of experience that the English language often recalls when dealing with emotion expressions about happiness and sadness.

\section{Cold Dark \\ Down Light \\ Up Warmth}

Arrange these areas as connected to each emotion (the first one has been done for you). After that, classify the expressions in the previous activity according to the areas of experience they belong to.

\begin{tabular}{|l|l|}
\hline \multirow{3}{*}{ HAPPINESS } & 1. UP \\
\cline { 2 - 2 } & 2. \\
\cline { 2 - 3 } & 3. \\
\hline \multirow{3}{*}{ SADNESS } & 1. \\
\cline { 2 - 2 } & 2. \\
\cline { 2 - 2 } & 3. \\
\hline
\end{tabular}


4. Why do you think we use these expressions?

5. Are there the same expressions, similar or equivalent ones in your mother tongue? In general terms, do you use the same associations (conceptual metaphors) in your mother tongue in order to make reference to the same emotions?

6. Try to find images related to those emotions on the net (use Google and the guidance of your teacher). Can you predict the kind of situations, actions, colours and pictures you will find? Search for these emotions in different languages, is there any difference? 